\title{
ERRATUM
}

\section{Epilogue: Moving the Equity Agenda Forward Requires Transformative Action}

\author{
Alberto J. Rodriguez \\ J.A. Bianchini et al. (eds.), Moving the Equity Agenda Forward: Equity Research, \\ Practice, and Policy in Science Education, Cultural Studies of Science Education 5, \\ DOI 10.1007/978-94-007-4467-7, () Springer Science+Business Media Dordrecht 2013
}

DOI 10.1007/978-94-007-4467-7_23

This title is published with the Epilogue as part of the book back matter. In the corrected publication the Epilogue is replaced as Chapter 22. 
